\title{
Zooplankton community and hydrographical properties of the Neretva Channel (eastern Adriatic Sea)
}

\author{
Olja Vidjak · Natalia Bojanić · Grozdan Kušpilić • \\ Živana Ninčević Gladan · Vjekoslav Tičina
}

Received: 8 November 2006/Revised: 6 June 2007/ Accepted: 6 June 2007/Published online: 11 July 2007

(C) Springer-Verlag and AWI 2007

\begin{abstract}
Temporal and spatial variability of micro and mesozooplankton was studied in 1998 and 1999 at four stations in the Neretva Channel area influenced by the Neretva river and the open waters of the south Adriatic Sea. The area is orthophosphate limited, but an excessive accumulation of land derived nitrogen is prevented by phytoplankton uptake and the general circulation pattern. Microzooplankton was dominated by ciliates, with average abundances comparable to other Adriatic channel areas (122-543 ind. $~^{-1}$ ). Non-loricate ciliates (NLC) generally peaked in the warmer periods, but a winter increase was evident towards the inner part of the channel. Tintinnid abundances generally increased in autumn. A significant relationship with temperature was not recorded for either protozoan group. An inverse relationship between NLC and salinity might be indirectly caused by their preference for the food abundant surface layer. Mesozooplankton was dominated by copepods, with distinct summer maxima throughout the area and pronounced winter maxima of $>10,000$ ind. $\mathrm{m}^{-3}$ at the inner stations. The community was predominantly neritic but the open sea waters were important in structuring the mesozooplankton assemblage at all stations during the autumn-winter period. Although temperature regulated the seasonal dynamics of most metazoans and the species succession in the copepod community, small omnivorous copepods (Oncaea media complex, Oithona nana and Euterpina acutifrons) domi-
\end{abstract}

Communicated by H.D. Franke.

O. Vidjak $(\bowtie) \cdot$ N. Bojanić · G. Kušpilić ·

Ž. Ninčević Gladan · V. Tičina

Institute of Oceanography and Fisheries,

Šetalište I. Meštrovića 63, 21000 Split, Croatia

e-mail: vidjak@izor.hr nated regardless of the season. A trophic link between copepods and ciliates was evident in winter during low phytoplankton biomass.

Keywords Adriatic Sea - Microzooplankton · Mesozooplankton $\cdot$ Neretva Channel

\section{Introduction}

Although the waters of the Neretva Channel have been sampled regularly during the last decade, published data on plankton community are still scarce. Most published work deals with the shallow and naturally eutrophicated Mali Ston Bay, an important shellfish farming area situated at the Channel's inner end (Rudenjak-Lukenda 1990; Lučić and Onofri 1990; Viličić et al. 1994; Lučić and Kršinić 1998). Compared to the Mali Ston Bay, the channel waters have been reported to show lower phyto and zooplankton abundances (Kršinić and Mušin 1981; Viličić 1981). However, acoustic surveys consistently showed high echo integral values in the Neretva Channel and fish samples confirmed high abundances of adult and juvenile planktivorous fish, indicating that this area represents an important feeding and nursery ground for many pelagic fish species (Tičina et al. 2006).

The major contrasting influences in the area are the Neretva river, with an annual average runoff of $378 \mathrm{~m}^{3} \mathrm{~s}^{-1}$ (Raicich 1994), and the intrusion of the highly saline oligotrophic waters from the open sea (Zore-Armanda et al. 1999), characterized by the high species diversity and reduced phyto and zooplankton abundances (Viličić 1989; Kršinić 1998). River estuaries are known as highly productive areas, where increased nutrient loading leads to increased phytoplankton production, which in turn supports 
high zooplankton abundance (Caddy and Bakun 1995; Lawrence et al. 2004). The transport of the estuarine waters to the outer estuary is highly variable and subjected to numerous influences (i.e. tidal mixing, topography, season, local winds, etc.) which can significantly increase or reduce their contribution to the productivity in the area. The resulting hydrological characteristics can greatly influence the population structure and seasonal variability of the zooplankton assemblage.

Due to limitations in respective sampling techniques, micro and mesozooplankton are often studied separately. However, evidence of their complex relationships have become apparent in recent years (Kleppel 1993; Gismervik and Andersen 1997; Nakamura and Turner 1997), showing the importance of including both categories in a comprehensive zooplankton study of an area. Therefore we aimed to examine temporal and spatial patterns of both micro and mesozooplankton component of the Neretva Channel zooplankton, in relation to the hydrographical characteristics of the area.

\section{Methods}

\section{Study area}

The Channel waters extend between the mainland and the Pelješac peninsula (Fig. 1). The coasts are sparsely populated and industrialized. The area is influenced by a considerable freshwater discharge from the Neretva river and several submarine springs situated inside the Mali Ston Bay. The highest Neretva river discharge typically occurs in spring (Vukadin 1981). Its estuary is classified as the salt-wedge type, where due to small tidal currents the advection of the river water is much larger than the introduction of seawater through tidal mixing. Vertical mixing is restricted to the thin transition layer between the freshwater at the surface and the salt water underneath. Horizontal extension of the freshwater into the Channel mostly depends on the direction of local winds, and recent measurements indicate that those can vary on a daily basis (Matić 2005).

Most of the mainland coast is built of highly permeable limestone without a natural barrier between the groundwaters of the carstic fields in the hinterland and the freshwater submarine springs in the Bay of Mali Ston (Bahun 1981). Higher discharge of the submarine springs in winter causes a spreading of the less saline surface waters into the Neretva Channel and a compensatory inflow in the bottom layer. The strong NE "bora" wind can, however, reverse that circulation. During the summer the circulation pattern depends entirely on the wind direction (Vučak et al. 1981).

\section{Sampling methods}

Sampling was performed at four stations in the Neretva Channel in May, July, August, September and November 1998 and February, April, May, June, August and October 1999 (Fig. 1). The geographic positions and depths of the sampling stations are presented in Table 1.

Microzooplankton samples were collected with a 51 Niskin bottle at $0,5,10,20$ and $30 \mathrm{~m}$ depths. The samples were preserved in $2.5 \%$ formaldehyde-seawater solution, previously buffered with $\mathrm{CaCO}_{3}$, since Lugol's solution stains detritus and would reduce visibility (Fonda-Umani and Beran 2003). Preparation of the samples for the microscopic analysis was performed as described in Bojanić et al. (2005). Counting and species identification were performed with an inverted microscope at $100 \times$ and $400 \times$ magnifications. Abundances were expressed as number of individuals per litre (ind. $\mathrm{l}^{-1}$ ).
Fig. 1 Study area with the sampling stations

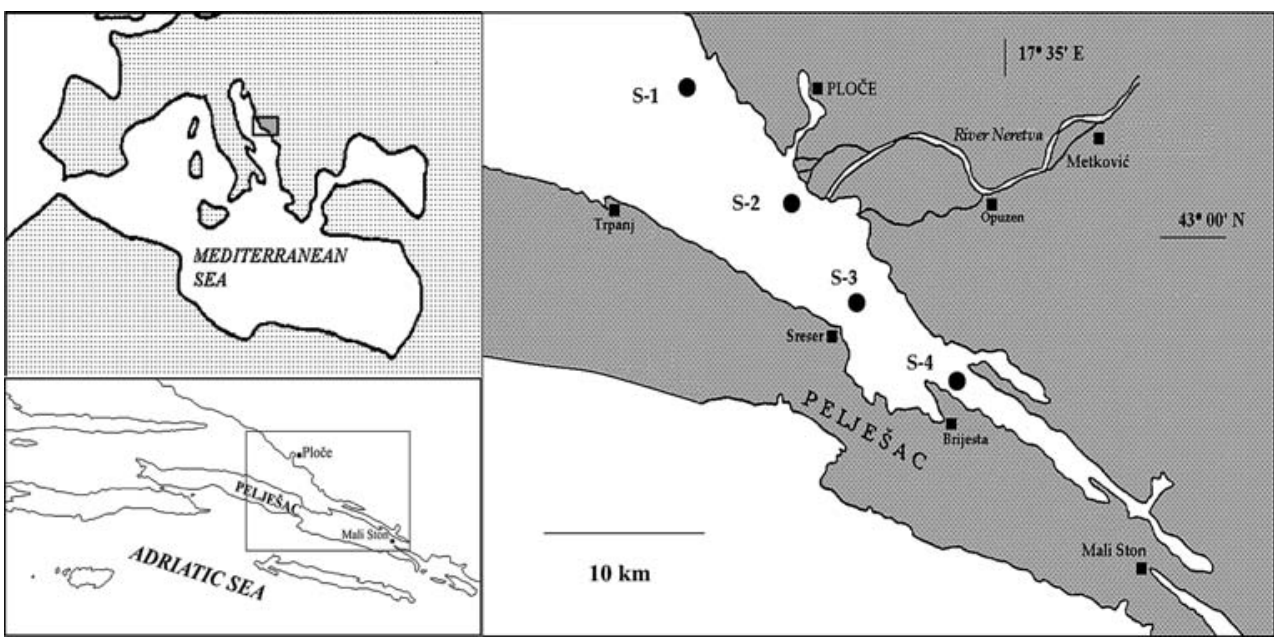


Table 1 Geographic positions and depths of sampled stations

\begin{tabular}{llll}
\hline Station & Geographic position & $\begin{array}{l}\text { Sampling } \\
\text { depth }(\mathrm{m})\end{array}$ \\
\hline S-1 & $43^{\circ} 03^{\prime} 06^{\prime \prime} \mathrm{N}$ & $17^{\circ} 21^{\prime} 18^{\prime \prime} \mathrm{E}$ & 30 \\
S-2 & $43^{\circ} 01^{\prime} 30^{\prime \prime} \mathrm{N}$ & $17^{\circ} 24^{\prime} 48^{\prime \prime} \mathrm{E}$ & 18 \\
S-3 & $42^{\circ} 58^{\prime} 00^{\prime \prime} \mathrm{N}$ & $17^{\circ} 27^{\prime} 42^{\prime \prime} \mathrm{E}$ & 20 \\
S-4 & $42^{\circ} 55^{\prime} 18^{\prime \prime} \mathrm{N}$ & $17^{\circ} 33^{\prime} 18^{\prime \prime} \mathrm{E}$ & 20 \\
\hline
\end{tabular}

Parallel sampling of the mesozooplankton was performed at the same stations, using a $125 \mu \mathrm{m}$ mesh size Nansen net $\left(57 \mathrm{~cm}\right.$ diameter, $0.255 \mathrm{~m}^{2}$ mouth area, total length $2.5 \mathrm{~m}$ ) hauled from near-bottom to the surface. Organisms were preserved with the same fixative. Analysis of the subsamples (1/16-1/64 of the total sample) was performed with an inverted microscope at $40 \times$ and $400 \times$ magnifications, and the entire sample was checked for the rare species. Abundances were expressed as number of individuals per cubic meter (ind. $\mathrm{m}^{-3}$ ). Adult copepods and copepodids were always counted separately. Taxonomic identification of mesozooplankton organisms was, whenever possible, performed to the species level. An exception is the copepod family Oncaeidae where recent reviews have suggested substantial taxonomic changes (BöttgerSchnack and Huys 2001; Böttger-Schnack et al. 2001, 2004). In the present study the triplet of sibling species Oncaea media-O. scottodicarloi-O. waldemari was counted as the $O$. media complex, Monothula subtilis was determined to species level, and all other oncaeids were pooled and counted as Oncaea spp.

Vertical temperature and salinity profiles were measured with a CTD multiparameter probe (IDRONAUT OS316). Oxygen concentrations were determined by the Winkler method (Grasshof 1976). Nutrient concentrations were determined on the Auto-Analyser III system, using modified automated methods (Grasshof 1976). Chlorophyll $a$ measurements were performed on the Turner 112 fluorometer following acetone extraction (Strickland and Parsons 1972). Taxonomic identification of the phytoplankton was performed with an inverted microscope at $200 \times$ magnification following the Utermöhl sedimentation method (Utermöhl 1958).

Non-parametric Kruskal-Wallis test was used to test the differences in total micro or mesozooplankton abundances among the sampling stations. Non-parametric Spearman rank order correlations were used to assess the influence of the environmental variables on the mesozooplankton groups and species, and intergroup relationships within the zooplankton community. Principal component analysis (PCA) based upon the correlation matrix was performed to identify the similarities in zooplankton variability among investigated sites. The data input consisted of a set of variables representing average monthly abundances of the main micro and all mesozooplankton groups. The Varimax rotation of extracted PCA components was used in order to obtain a better insight into the behavior of observation variables. The above mentioned analyses were performed using the statistical package StatSoft Inc. (2000) STATISTICA for Windows version 5.5 (http://www.statsoft.com).

Shannon diversity index was used to analyse seasonal diversity changes in the copepod community. In order to reveal copepod species contributions to the dissimilarities among the sampling seasons and to identify the seasonal pattern in the copepod population, Similarity percentages analysis (SIMPER) was performed on the copepod abundance matrix $\log (x+1)$ transformed data, with the cut off for low contributions fixed at $75 \%$. Seasons were determined on the basis of the temperature vertical gradient and termocline formation, and labels such as "spring" (April, May), "summer" (June, July, August), "autumn" (September, October, November) and "winter" (February) were assigned to the individual samples and used as factor groups. This analysis also identified characteristic copepod seasonal ranking, along with their individual contributions based on their averaged abundances during the particular season. The above mentioned analyses were performed using the statistical package Primer 5, version 5.2.9 (Clarke and Gorley 2001).

\section{Results}

Abiotic and biotic environmental variables

\section{Temperature}

The seasonal temperature cycle was remarkably similar among the sampling stations (Fig. 2a). Highest fluctuations were recorded at the surface. Summer periods (JulyAugust 1998 and June-August 1999) were characterized by a stratified water column and a thermocline at 10 or $20 \mathrm{~m}$ depth. Maximum surface temperature values were recorded in August 1998 at all stations, ranging from 24.78 to $25.47^{\circ} \mathrm{C}$. The thermocline disappeared in September 1998 when the water column became isothermal at all stations and a slight temperature inversion was recorded occasionally. Lowest temperature values were recorded in February 1999 at all stations, ranging from 9.34 to $10.86^{\circ} \mathrm{C}$ and coinciding with the appearance of less saline $(<35.50)$ water at the surface. In May 1999 surface temperature increased again which resulted in the formation of a thermocline during summer 1999. In October 1999 the water column became isothermal, but the average temperatures were higher than those recorded in August at all stations. 
Fig. 2 Seasonal variability of a temperature, and $\mathbf{b}$ salinity in the Neretva Channel $\mathbf{a}_{28}$

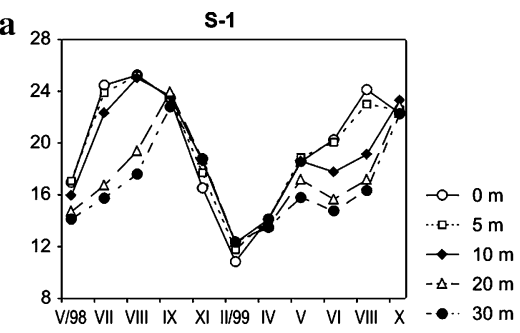

S-2

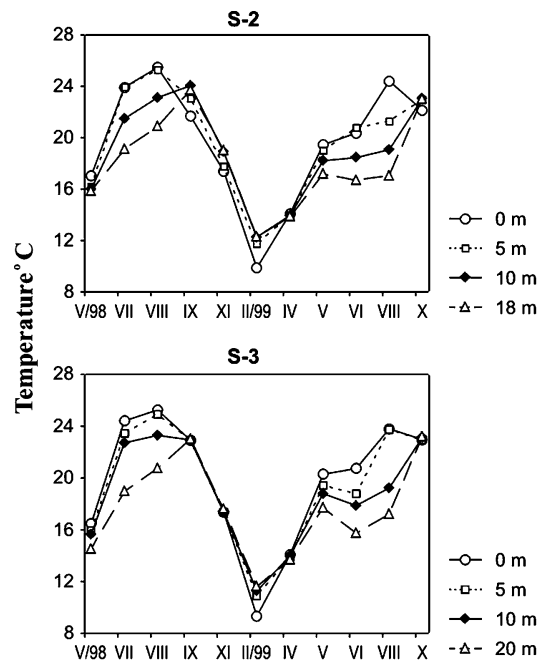

s-4

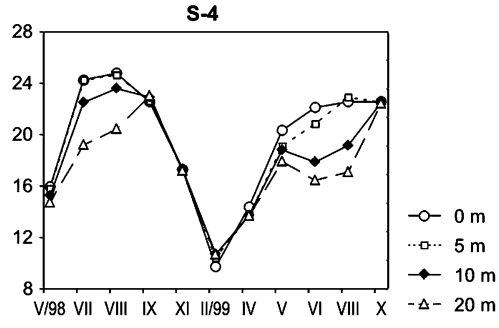

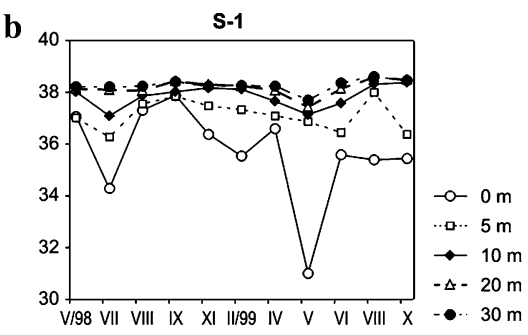

S-2

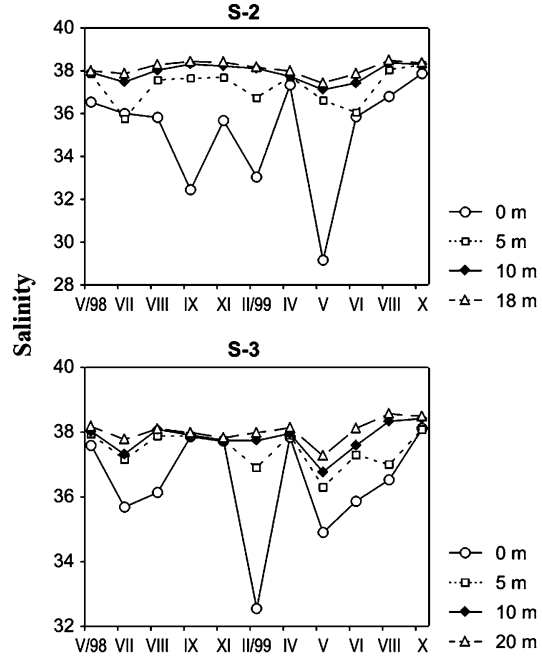

S-4

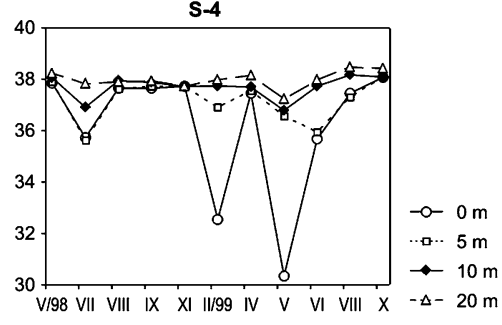

Months

\section{Salinity}

Large surface salinity oscillations were recorded in the area, ranging from 29.15 (May 1999) to 38.11 (October 1999) (Fig. 2b). Pronounced occurrence of low salinity surface water and a strong vertical gradient was recorded at all stations in February and May 1999, but the halocline was generally positioned well above $5 \mathrm{~m}$ depth. Salinity increased with depth, and the oscillations were low in the bottom layer. Highest values were recorded in August 1999 in the bottom layer at all investigated stations (38.4838.61).

\section{Oxygen concentration and saturation}

The water column was well-oxygenated and no anoxic layers were found. Oxygen concentration ranged from 4.41 to $6.61 \mathrm{ml} \mathrm{l}^{-1}$, corresponding to 94.90 and $115.76 \% \mathrm{O}_{2}$, respectively. Lowest values were recorded in August 1998
(S-1 and S-2) and September 1999 (S-3 and S-4) at the surface (S-2) or $10 \mathrm{~m}$ depth. The highest oxygen saturations were recorded in April 1999 at S-1 and S-2 at the surface (115.00 and $115.76 \% \mathrm{O}_{2}$, respectively) and corresponded to high biological productivity. At stations S-3 and S-4 the concentrations were highest in February 1999, corresponding to low surface water temperature $\left(<10^{\circ} \mathrm{C}\right)$ and oxygen saturation of 98.14 and $99.03 \%$, respectively.

\section{Nutrients concentrations}

Higher concentrations of total inorganic nitrogen in the water column were generally recorded in the autumnwinter period, with a maximum of $7.44 \mathrm{mmol} \mathrm{m}^{-3}$ in November 1998 at S-2 (Fig. 3a). In April 1999 surface inorganic nitrogen content increased at the outer stations $\mathrm{S}$ 1 and $\mathrm{S}-2$ ( $\left.>4 \mathrm{mmol} \mathrm{m}^{-3}\right)$, and was extremely low at the inner stations S-3 and S-4 $\left(<0.5 \mathrm{mmol} \mathrm{m}^{-3}\right)$. The further increase in surface inorganic nitrogen content in May 1999 
following the higher influx of the Neretva river freshwater was pronounced at $\mathrm{S}-1\left(7.43 \mathrm{mmol} \mathrm{m}{ }^{-3}\right)$, and considerably lower at other stations. Dominant nitrogen form was nitrate, while ammonia concentrations were somewhat higher in November 1998 and May 1999.

Increased concentrations of orthosilicate were also recorded in autumn-winter (November 1998 and February 1999) and in spring (May 1999) (Fig. 3b). Despite the relatively high surface salinity ( $>36.60$ ) in April 1999, high orthosilicate content was determined in the surface waters of S-1 and S-2 (23.41 and $14.96 \mathrm{mmol} \mathrm{SiO}_{4} \mathrm{~m}^{-3}$, respectively), coinciding with the high chlorophyll $a$ biomass at the surface.

Ortophosphate concentrations were low throughout the investigated area (Fig. 3c). Average column values of $<0.1 \mathrm{mmol} \mathrm{m}^{-3}$ were recorded through most of the investigated period. Average Redfield ratio values $\left(\Sigma N_{\text {inorg }} / \mathrm{P}\right)$ over the investigated period varied between $19.34 \pm 15.38$ and $22.24 \pm 17.25$ among stations. However, at the very surface $(0 \mathrm{~m})$, those values varied between $33.67 \pm 35.13$ and $95.21 \pm 237.89$ (Table 2).

\section{Phytoplankton}

Average column chlorophyll $a$ values in the investigated area ranged from $0.03 \pm 0.02$ to $0.96 \pm 0.25 \mathrm{mg} \mathrm{chl} a \mathrm{~m}^{-3}$ (Fig. 4). The most prominent feature of the phytoplankton seasonal cycle was the occurrence of a spring maximum in April 1999, exceeding $1 \mathrm{mg}$ chl $a \mathrm{~m}^{-3}$ at the outer (S-1 and
Table 2 Average Redfield ratio $\left(\Sigma N_{\text {inorg }} / \mathrm{P}\right)$ in the water column $(0 \mathrm{~m}$ bottom) and at the surface $(0 \mathrm{~m})$ during the investigated period

\begin{tabular}{lll}
\hline Station & \multicolumn{2}{l}{$\sum N_{\text {inorg }} / \mathrm{P}$} \\
\cline { 2 - 3 } & $0 \mathrm{~m}$ bottom & $0 \mathrm{~m}$ \\
\hline $\mathrm{S}-1$ & $21.60 \pm 15.37$ & $36.93 \pm 28.89$ \\
$\mathrm{~S}-2$ & $22.24 \pm 17.25$ & $72.59 \pm 71.71$ \\
$\mathrm{~S}-3$ & $19.64 \pm 17.83$ & $95.21 \pm 237.89$ \\
S-4 & $19.34 \pm 15.38$ & $33.67 \pm 35.13$ \\
\hline
\end{tabular}

$\mathrm{S}-2$ ), and $0.5 \mathrm{mg}$ chl $a \mathrm{~m}^{-3}$ at the surface of the inner stations (S-3 and S-4). During the increased discharge of the Neretva river in May 1999 phytoplankton biomass at the surface generally exceeded $0.5 \mathrm{mg}$ chl $a \mathrm{~m}^{-3}$. At stations S-3 and S-4 phytoplankton exhibited a second maximum in autumn (November 1998) which was absent at the outer stations. Lowest average column values usually occurred in October, except at S-3 where it was recorded in August.

Microphytoplankton size fraction dominated by diatoms prevailed in the population. The occurrence of monospecific blooms was not recorded.

\section{Microzooplankton}

Total microzooplankton abundance per station ranged between 122 and 543 ind. $1^{-1}$. Ciliated protozoa dominated the assemblage; the average abundances fluctuated greatly
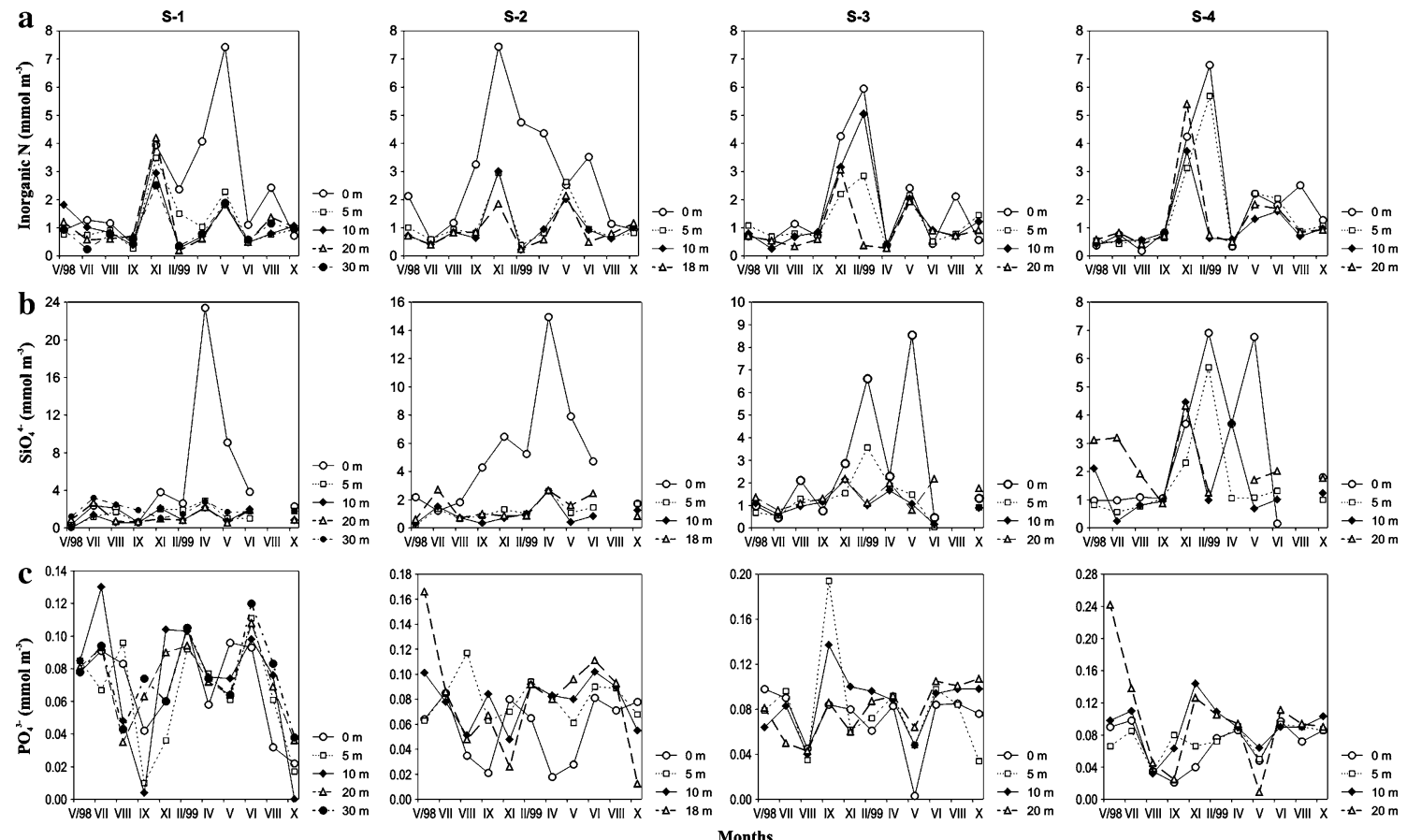

Fig. 3 Seasonal variability of nutrient concentrations in the Neretva Channel. a Inorganic nitrogen. b Orthosilicate. c Orthophosphate 

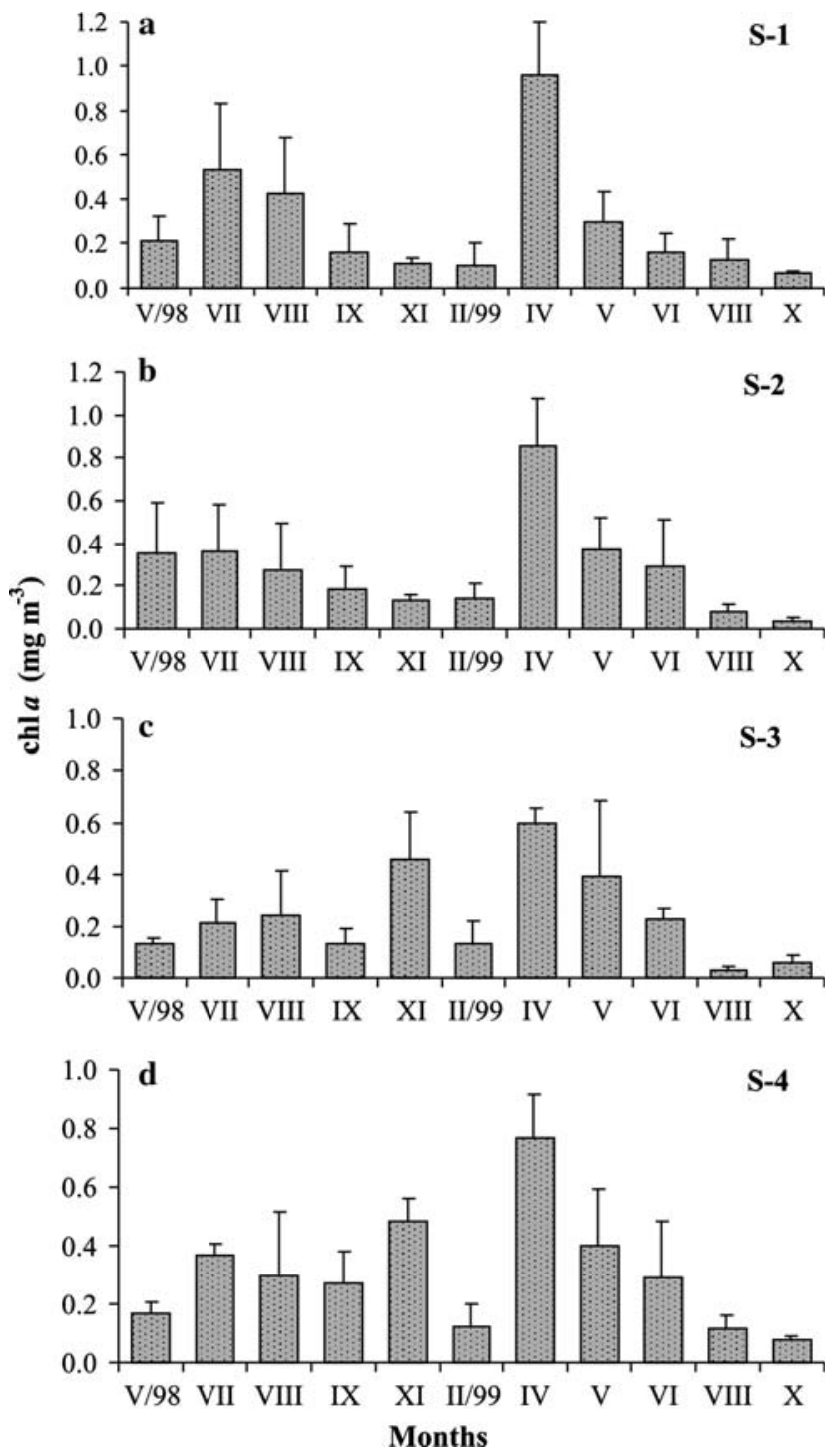

Fig. 4 Seasonal variability of average chlorophyll $a$ concentrations at stations a S-1, b S-2, c S-3, and d S-4 (standard deviation is indicated by vertical bars)

during the investigated period, ranging between 81 and 431 ind. $1^{-1}$. The differences among stations were not significant $(P=0.963)$.

Non-loricate ciliates (NLC) dominated this group, especially in the warmer periods (Fig. 5). At stations S-1 and S-2 highest abundances of NLC were recorded at the surface during the summer maximum. The same vertical pattern was determined during the spring NLC maximum (May 1999) recorded at stations S-3 and S-4. Only at the innermost station S-4 highest average abundance of NLC was recorded in February $1999\left(415 \pm 279\right.$ ind. $\mathrm{l}^{-1}$, Fig. 5d), with considerably increased abundance (770 ind. $\left.1^{-1}\right)$ at the bottom.

Increased tintinnid abundances generally occurred in autumn, with a relatively homogenous vertical distribution
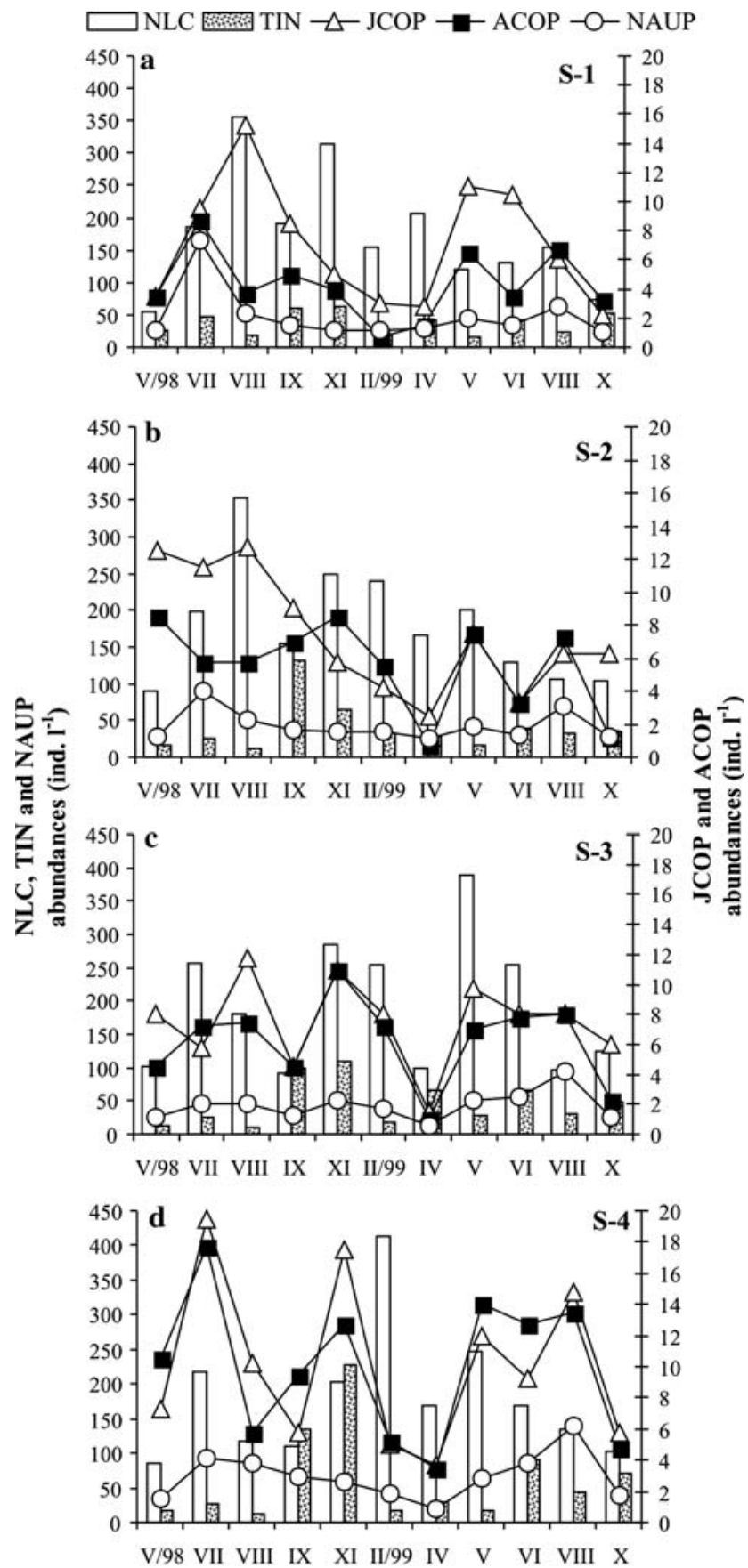

Months

Fig. 5 Seasonal distribution of average density of microzooplankton groups at stations a $\mathrm{S}-1, \mathbf{b} \mathrm{S}-2, \mathbf{c} \mathrm{S}-3$, and d S-4 (NLC non-loricate ciliates, TIN tintinnides, NAUP copepod nauplii, JCOP juvenile copepods, $A C O P$ adult small copepods)

at all investigated stations. The highest average value of $228 \pm 30$ ind. $\mathrm{l}^{-1}$ was determined at S-4 in November 1998 (Fig. 5d). A second abundance maximum, recorded in summer 1999 was of lower intensity.

During most of the investigated period average abundances of micrometazoa were lower than those recorded 
for protozoa. The differences between their total abundances were not significant among stations $(P=0.130)$.

Copepod nauplii were dominant, representing $>50 \%$ of total micrometazoa at all stations. They generally peaked in summer, with a maximal average abundance of $164 \pm 156$ ind. $1^{-1}$ in July 1999 at station S-1 (Fig. 5). Vertical distribution pattern of the copepod nauplii in that period showed maximal values in the surface layer $(0-5 \mathrm{~m})$. During the colder months decreased abundances ( $\sim 50$ ind. $\mathrm{l}^{-1}$ ) and a slight shift in the population distribution towards the bottom was recorded.

The average densities of juvenile copepods and adult small copepods were lower, and their temporal and vertical fluctuations during the sampling period less pronounced. Nevertheless, the seasonal and vertical distributions of the copepodids resembled those of the nauplii, with the highest values recorded in the spring-summer period above the $10 \mathrm{~m}$ depth (Fig. 5). The exception was noted at the station S-1, where in May and June 1999 the majority of this population was recorded in the bottom layer. In the late autumn-winter period the organisms also concentrated at the bottom, especially at the inner stations S-3 and S-4.

Increased abundances of adult small copepods were also found in the spring-summer period (Fig. 5). The maximum was recorded at the surface of station S-4 (27 ind. $\left.1^{-1}\right)$ in July 1998, when Paracalanus parvus, Euterpina acutifrons and Oithona nana dominated this category. At the other stations this summer maximum was of lower intensity, and the organisms concentrated in the $0-5 \mathrm{~m}$ layer. A somewhat increased abundance of adult small copepods was also recorded in the late autumn-winter period at S-3 (23 ind. $\mathrm{l}^{-1}$ ), with Oncaea spp. and E. acutifrons as the main contributors.

\section{Mesozooplankton}

Total mesozooplankton abundance per station varied from 2055 to 14797 ind. $\mathrm{m}^{-3}$ (Fig. 6). The differences among stations were not significant $(P=0.392)$. Highest abundances were generally recorded in the warmer part of the sampling period, but distinct peaks were also observed in February 1999 at the inner stations S-3 and S-4 (Fig. 6c, d).

Copepods were the most abundant group, and their average annual abundances represented $>60 \%$ of the total mesozooplankton.

Only in summer the contribution of cladocerans occasionally surpassed that of the copepods. Lowest cladoceran abundances were recorded in February 1999 at all stations, and the highest value (4949 ind. $\mathrm{m}^{-3}$ ) was recorded in June 1999 at S-1 (Fig. 6a). The most abundant species was Penilia avirostris.

Larval stages of benthic invertebrates generally ranged third in abundance, although they were occasionally
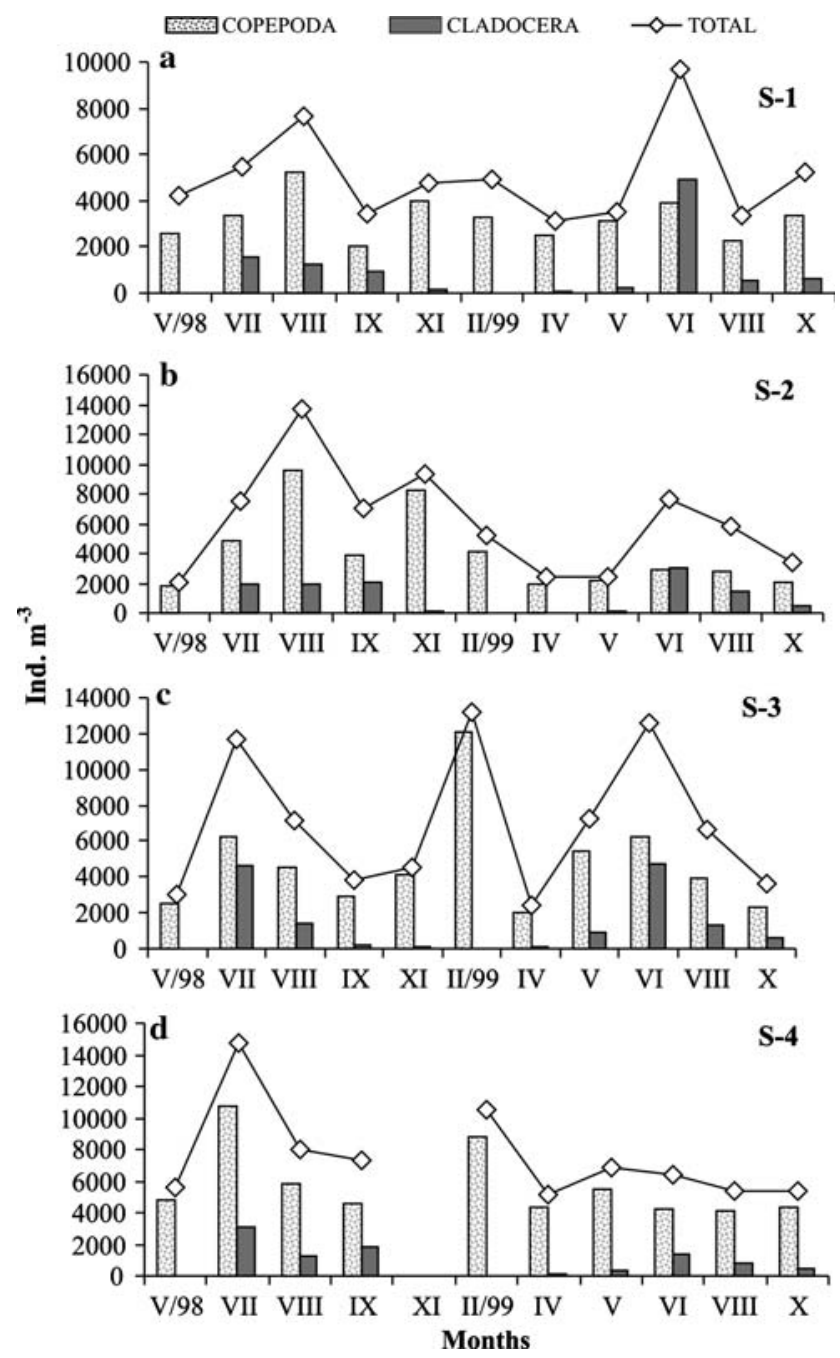

Fig. 6 Seasonal distribution of the abundances of total mesozooplankton and dominant mesozooplankton groups (Copepoda, Cladocera) at stations a S-1, b S-2, c S-3, and d S-4

surpassed by the appendicularians, especially in the summer-autumn period. Bivalve larvae dominated among the meroplankton larval stages.

Juveniles made the highest contribution to the appendicularian abundances, peaking in August and September 1998. The most abundant adult appendicularians were Oikopleura dioica (S-1 and S-2) and O. longicauda (S-3 and S-4). Small numbers of Fritillaria pellucida were recorded particularly in February 1999.

Chaetognaths were recorded throughout the investigated period, and were dominated by juvenile Sagitta spp.. Their overall contribution to the total mesozooplankton was $<4 \%$. Thaliaceans attained significant abundances in August 1998 when a high number of Doliolum spp. gonophores was recorded at all stations ( $>250$ ind. $\mathrm{m}^{-3}$ ), and in April 1999 when a Thalia democratica bloom was recorded at S-4 (294 ind. $\left.\mathrm{m}^{-3}\right)$. 
Other recorded groups included siphonophores, pteropods and ostracods. They appeared in the plankton occasionally and in low abundances. Siphonophores generally contributed $<1 \%$ to the total mesozooplankton. Increased pteropod abundances were recorded only in August 1999 at all stations, when high abundances of Creseis spp. embryonic shells appeared in the plankton. A small number of ostracods was recorded in the investigated area, mostly during the autumn-winter period.

A total of 44 copepod taxa was determined in the investigated area. The temporal variability of Shannon diversity index $\left(\mathrm{H}^{\prime}\right)$ for the copepod community is presented in Table 3.

Calanoids and poecilostomatoids generally dominated the copepod assemblage, while the dominance of the cyclopoids was mainly confined to warmer periods. Calanoid individual abundances were mostly low, but the number of species was relatively high, cumulatively contributing to the abundance of this group. Conversely, poecilostomatoids and cyclopoids in particular attained high individual abundances, but the number of species was lower.

Main contributors to the calanoid abundances were calanoid copepodids, representing on average $>70 \%$ of total calanoids at all stations. The most abundant and regularly occurring adult calanoids were Paracalanus parvus (Fig. 7a), Ctenocalanus vanus (Fig. 7b), Centropages typicus (Fig. 7c), Acartia clausi (Fig. 8a), and Temora stylifera (Fig. 8b). Temora longicornis showed increased abundances at the inner stations S-3 and S-4, with a maximum recorded in April 1999 at S-4 (410 ind. $\mathrm{m}^{-3}$ ) (Fig. 8c). Centropages krøyeri was recorded at all investigated stations, attaining highest abundance (102 ind. $\mathrm{m}^{-3}$ ) in July 1998 at the innermost station S-4. The presence of isolated specimens of some open-sea surface (Pontella spp., Labidocera wollastoni) or subsurface (Lucicutia flavicornis) dwellers was recorded at most stations throughout the investigated period.

The highest contribution to the poecilostomatoid copepods came from the Oncaea media complex, present and abundant throughout the area (Fig. 9a). Monothula subtilis density increased in the winter-spring period, when the species' contribution to the total poecilostomatoid abundance surpassed $20 \%$ (Fig. 9b).
The most abundant cyclopoid taxa at all stations were $O$. nana and Oithona copepodids (Fig. 9c). Their combined average annual abundances represented $>80 \%$ of this group at all stations.

Harpacticoid densities were low, and mainly controlled by the variability of the most abundant species $E$. acutifrons (Fig. 9d).

Zooplankton relationship to biotic and abiotic parameters

\section{Microzooplankton}

Non-loricate ciliates (NLC) showed a significant negative correlation with salinity at all stations. The relationship with temperature was mostly positive, but not significant for either NLC or tintinnids (Table 4).

Temperature rather than salinity showed a pronounced influence on the metazoan component of the microzooplankton community, evident in a mostly significant positive relationship with adult small copepods and their developmental stages (Table 4).

Correlation coefficients with the average chlorophyll $a$ concentrations were low for all microzooplankton groups (Table 4).

\section{Mesozooplankton}

Spearman rank order correlations showed that both cladocerans and appendicularians were effectively controlled by temperature (Table 4). Copepods as a group seemed to be unaffected by the temperature variability, but the response of the individual species was more specific. Ctenocalanus vanus, T. longicornis, M. subtilis and Oithona similis showed a consistently negative relationship with temperature, statistically significant at most stations. Correlation between $T$. stylifera and temperature was always positive and significant at most stations. Paracalanus parvus, Acartia clausi, Centropages typicus, the $O$. media complex, $O$. nana and $E$. acutifrons were less affected by temperature, evident in low correlation coefficients with this variable. Among other mesozooplankton groups, a

Table 3 Temporal variability of the Shannon diversity index $\mathrm{H}^{\prime}\left(\right.$ bits $_{\text {ind. }}^{-1}$ ) in the copepod community during the sampling period

\begin{tabular}{|c|c|c|c|c|c|c|c|c|c|c|c|c|}
\hline \multirow[t]{2}{*}{ Station } & \multicolumn{12}{|c|}{ Sampling period } \\
\hline & V 98 & VII & VIII & IX & XI & II 99 & IV & $\mathrm{V}$ & VI & VII & $X$ & Mean \\
\hline S-1 & 1.69 & 2.14 & 1.57 & 1.67 & 1.81 & 1.89 & 2.51 & 1.10 & 2.06 & 1.92 & 1.70 & 1.82 \\
\hline S-2 & 1.81 & 1.54 & 1.67 & 1.74 & 1.55 & 2.12 & 1.13 & 1.38 & 1.97 & 1.67 & 1.79 & 1.67 \\
\hline S-3 & 2.09 & 1.88 & 1.70 & 2.29 & 0.99 & 1.82 & 2.27 & 1.78 & 1.99 & 1.91 & 2.13 & 1.90 \\
\hline S-4 & 1.71 & 1.70 & 1.73 & 1.43 & - & 2.02 & 2.22 & 1.53 & 2.17 & 1.41 & 1.56 & 1.75 \\
\hline
\end{tabular}



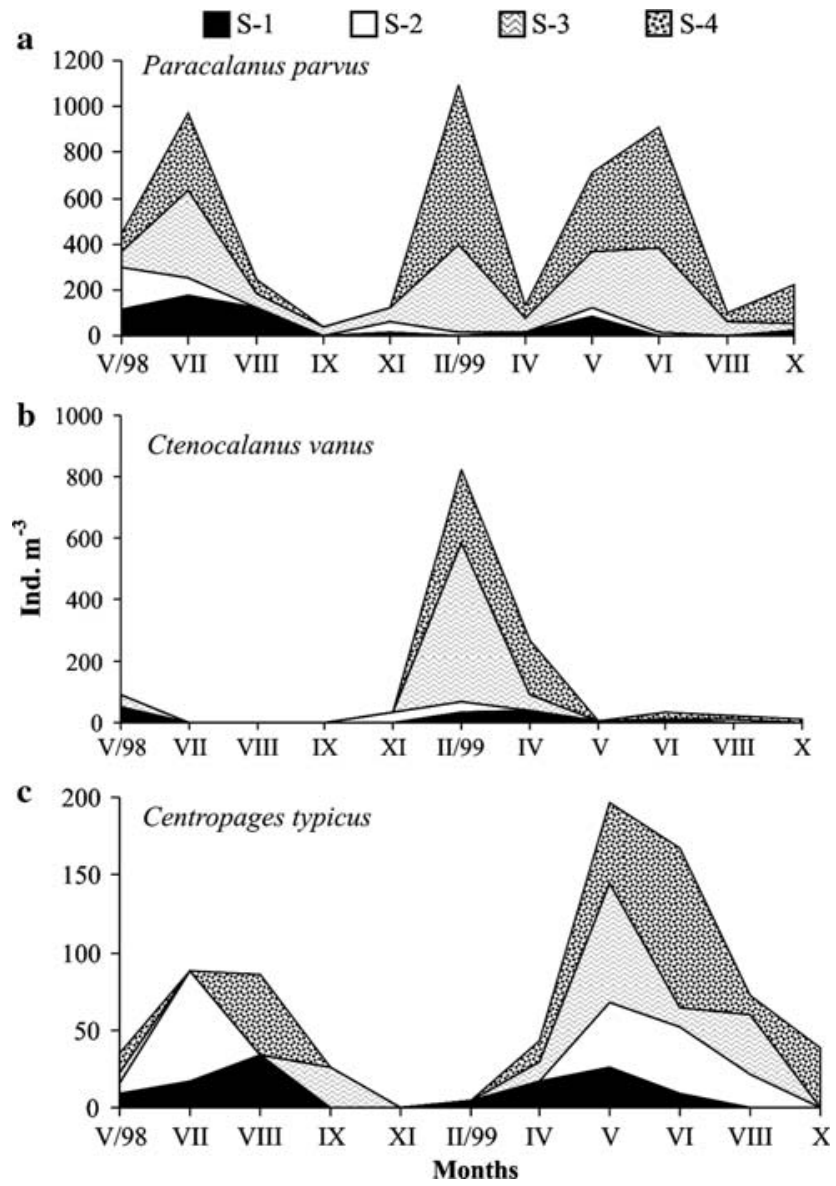

Fig. 7 Seasonal distribution of calanoid copepod species abundances. a Paracalanus parvus, b Ctenocalanus vanus, and c Centropages typicus at stations S-1 to S-4

significant relationship with temperature was determined only for thaliaceans at S-2 (Table 4).

Both total mesozooplankton and copepods consistently showed a negative relationship with salinity. However, a significant negative relationships with this parameter were determined for Paracalanus parvus and calanoid copepodids, the $O$. media complex and $E$. acutifrons only at station S-3, and for calanoid copepodids at S-4. Among the other groups, only pteropods at S-2 showed a significant correlation with salinity (Table 4).

Correlation coefficients with the average chlorophyll $a$ concentrations were low for most of the mesozooplankton groups. Significant relationships with this parameter were occasionally determined for Centropages typicus, calanoid copepodids, the $O$. media complex, thaliaceans and appendicularians (Table 4).

Between-group analysis

Fluctuations in the total mesozooplankton were primarily due to the seasonal variability of copepod abundances
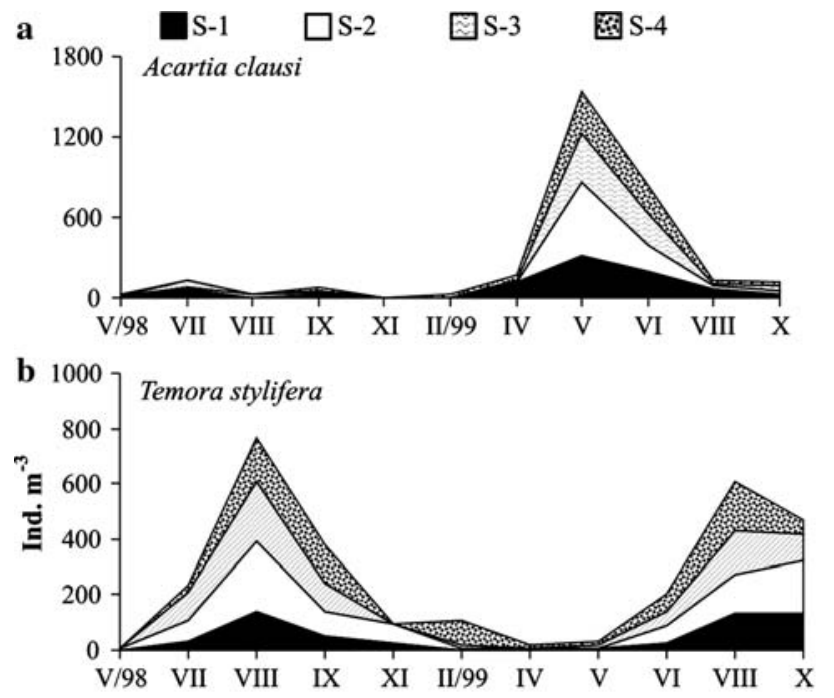

c

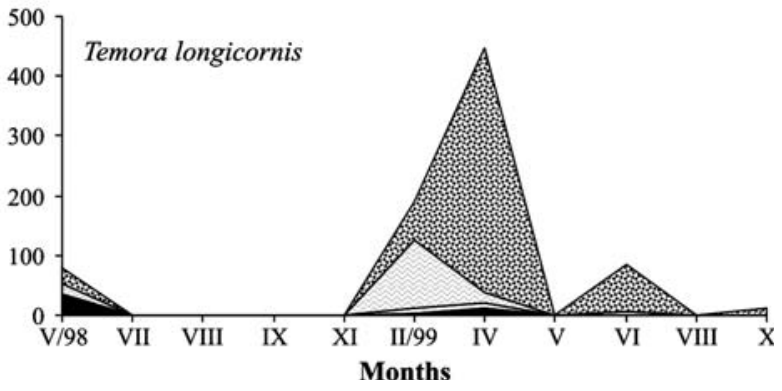

Fig. 8 Seasonal distribution of calanoid copepod species abundances. a Acartia clausi, b Temora stylifera, and c Temora longicornis at stations S-1 to S-4

(Table 5). Among mesozooplankton groups significant correlations originating from either predator-prey relationships (chaetognaths with copepods, cladocerans and meroplankton larvae) or similar food preferences (cladocerans with appendicularians and pteropods, appendicularians with pteropods) were recorded (Table 5).

Non-loricate ciliates showed a significant correlation with total copepods, calanoids and cyclopoids at S-2, as well as with poecilostomatoids at S-3 (Table 6). Tintinnids were significantly correlated with poecilostomatoids at S-4. Other significant correlations were determined mostly between copepods and their developmental stages.

Similarity percentages analysis (SIMPER)

Three copepod taxa ranked among the top five, regardless of the season: the $O$. media complex, $O$. nana and $E$. acutifrons. However, their position in this group varied, as the consequence of some variability in their abundances. The $O$. media complex always ranked first, with the exception of the winter period when E. acutifrons peaked. Oithona nana exhibited a significant peak in summer. 

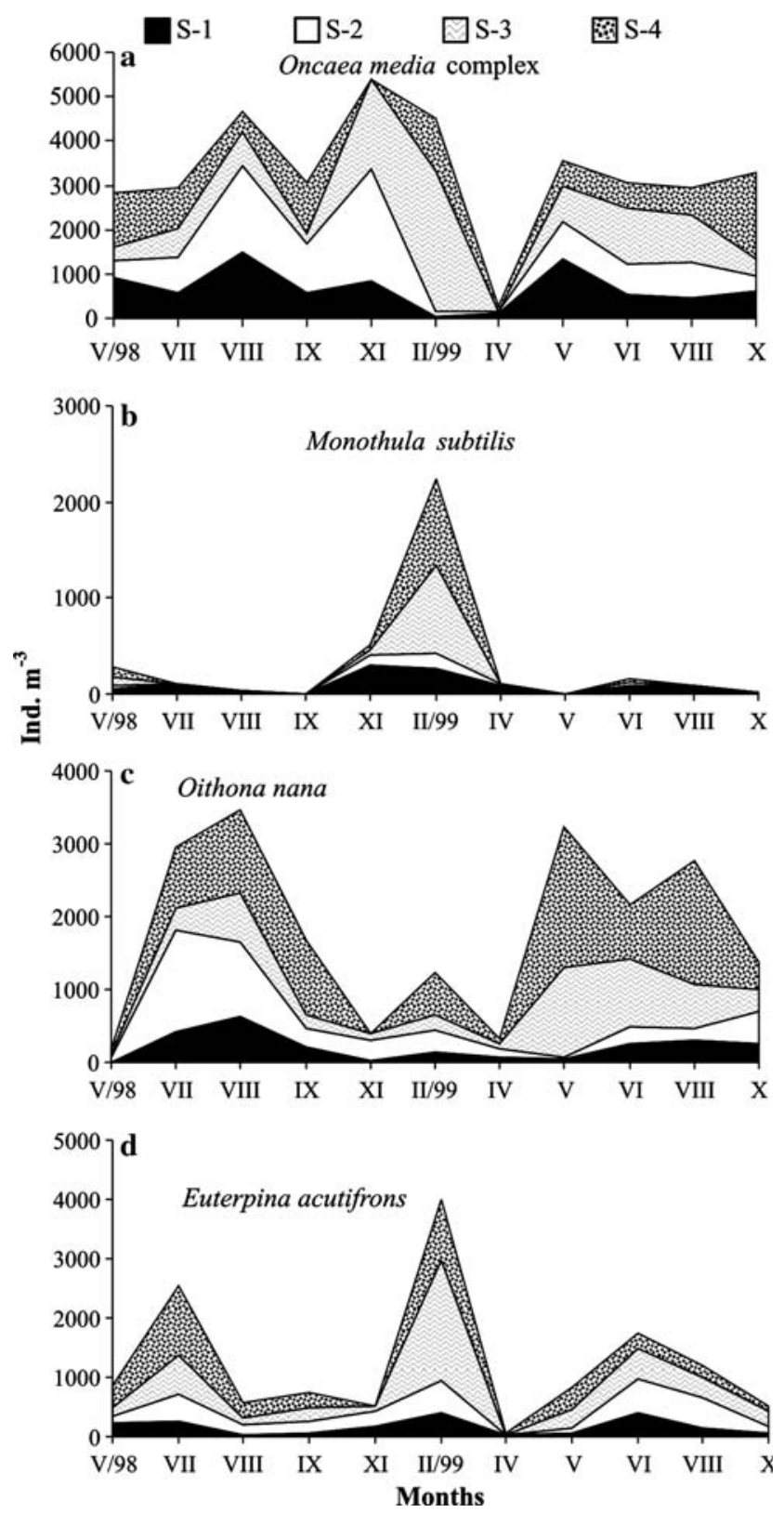

Fig. 9 Seasonal distribution of non-calanoid copepod species abundances. a Oncaea media complex, b Monothula subtilis, c Oithona nana, and $\mathbf{d}$ Euterpina acutifrons at stations S-1 to S-4

Cross comparisons of the copepod community during different seasons revealed further differences in seasonal copepod population structure. Acartia clausi was characteristic of the spring-summer community, Centropages krøyeri characterized the summer, T. stylifera the summerautumn, and Clausocalanus furcatus the autumn community. Temora longicornis was a characteristic part of the winter-spring, and M. subtilis and Ctenocalanus vanus of the winter assemblage. Paracalanus parvus contributed less to the dissimilarities among seasons, since it was almost perennial at the inner stations.
Principal components analysis (PCA)

Data input in the PCA included the main groups of the microzooplankton (non-loricate ciliates, tintinnids and copepod nauplii) and all mesozooplankton components (calanoid, cyclopoid, poecilostomatoid and harpacticoid copepods, cladocerans, appendicularians, chaetognaths, thaliaceans, pteropods, siphonophores, ostracods and larvae) recorded at four investigated sites. The PCA extracted two components which together accounted for $90.71 \%$ variance (Fig. 10). The PC1, comprising S-1 and S-2, explained $80.01 \%$ variance, while PC2 (S-3 and S-4) explained $10.70 \%$ variance.

\section{Discussion}

Due to the relatively low degree of urbanization and industrialization of the surrounding coasts, the anthropogenic influence on the nutrient dynamics in the Neretva Channel is limited. Maximum nitrate and silicate concentrations were recorded in spring, coinciding with reduced salinity at the surface and indicating that this nutrient enrichment came from the Neretva river discharge. The exception was noted in April 1999 when high nitrate and silicate surface content coincided with the relatively high surface salinity at outer stations S-1 and S-2 (36.60 and 37.30, respectively). However, vertical salinity changes in the $0-5 \mathrm{~m}$ layer during the investigated period suggested that the halocline is often positioned just below the surface, and it is thus possible that the freshwater influenced thin layer was not properly registered by the probe. The higher input of land-derived nitrogen was regulated by the quick spring phytoplankton uptake and further increase in nitrate concentration was evident only at station S-1, where the influence of Neretva river was most pronounced. Furthermore, circulation pattern in the Channel and the strong compensatory inflow of the open sea waters also affect nitrogen distribution, preventing a strong accumulation (Vukadin 1981).

The critical orthophosphate concentration separating between more and less productive Adriatic waters is $0.2 \mu \mathrm{mol} \mathrm{PO}_{4}^{3-} \mathrm{l}^{-1}$ (Viličić 1989). Throughout the study area it was significantly lower, designating orthophosphate as the limiting nutrient. Similar N/P stoichiometry is often determined in the coastal waters of the Adriatic Sea (Viličić and Stojanoski 1987). During the phytoplankton peaks chlorophyll $a$ values were much lower compared to those recorded inside the Mali Ston Bay, where up to $6.73 \mu \mathrm{g} \mathrm{chl} a 1^{-1}$ was recorded during the bloom (Viličić et al. 1998).

In the absence of strong anthropogenic impacts, seasonality and population structure of the coastal zooplankton are largely determined by the physical environmental 


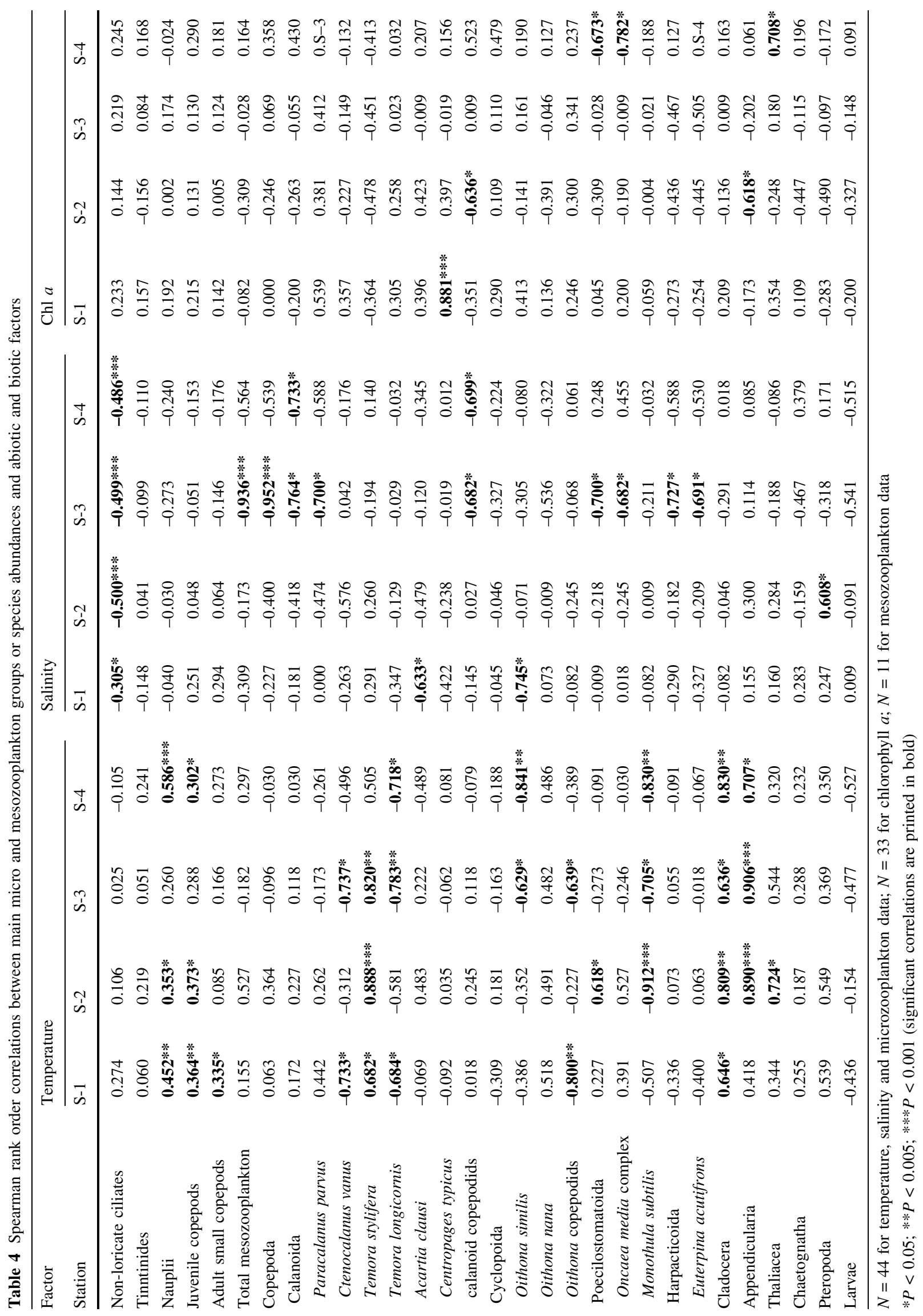


Table 5 Spearman rank order correlations between main mesozooplankton groups
COP Copepoda, CLADO

Cladocera, APP

Appendicularia, CHAETO

Chaetognatha, PTERO

Pteropoda

$N=11 ; * P<0.05$

$* * P<0.005 ; * * * P<0.001$

(significant correlations are

printed in bold)

\begin{tabular}{|c|c|c|c|c|c|c|}
\hline & \multicolumn{6}{|c|}{ Mesozooplankton groups } \\
\hline & Total & $\mathrm{COP}$ & CLADO & APP & CHAETO & PTERO \\
\hline \multicolumn{7}{|l|}{$\mathrm{COP}$} \\
\hline S-1 & $0.846^{* * *}$ & & & & & \\
\hline S-2 & $0.900 * *$ & & & & & \\
\hline S-3 & $0.980 * * *$ & & & & & \\
\hline S-4 & $0.806 * *$ & & & & & \\
\hline \multicolumn{7}{|c|}{ CLADO } \\
\hline S-1 & 0.554 & 0.355 & & & & \\
\hline $\mathrm{S}-2$ & $0.700 * *$ & 0.418 & & & & \\
\hline S-3 & 0.427 & 0.351 & & & & \\
\hline S-4 & 0.346 & -0.042 & & & & \\
\hline \multicolumn{7}{|l|}{ APP } \\
\hline S-1 & $0.636^{*}$ & 0.564 & 0.473 & & & \\
\hline S-2 & 0.582 & 0.418 & $0.655^{*}$ & & & \\
\hline S-3 & -0.014 & -0.100 & 0.596 & & & \\
\hline S-4 & 0.146 & 0.006 & 0.567 & & & \\
\hline \multicolumn{7}{|c|}{ CHAETO } \\
\hline S-1 & $0.665^{*}$ & 0.706* & $0.410 *$ & 0.565 & & \\
\hline S-2 & $0.836 * *$ & $0.845 * *$ & 0.333 & 0.365 & & \\
\hline S-3 & 0.375 & 0.417 & 0.481 & 0.323 & & \\
\hline S-4 & -0.067 & 0.080 & 0.190 & -0.258 & & \\
\hline \multicolumn{7}{|c|}{ PTERO } \\
\hline S-1 & 0.356 & 0.137 & 0.397 & 0.753* & 0.192 & \\
\hline S-2 & 0.430 & 0.105 & $0.609 *$ & $0.645^{*}$ & 0.257 & \\
\hline S-3 & 0.401 & 0.360 & $0.820 * *$ & 0.303 & 0.441 & \\
\hline S-4 & -0.067 & -0.425 & 0.306 & -0.060 & 0.241 & \\
\hline \multicolumn{7}{|c|}{ LARVAE } \\
\hline S-1 & 0.272 & 0.200 & -0.436 & 0.318 & 0.177 & 0.132 \\
\hline S-2 & 0.509 & 0.446 & 0.282 & -0.064 & $0.616 *$ & 0.292 \\
\hline S-3 & 0.560 & 0.491 & 0.156 & -0.354 & 0.213 & 0.279 \\
\hline S-4 & 0.418 & 0.394 & -0.224 & -0.396 & -0.184 & -0.455 \\
\hline
\end{tabular}

variables. Average abundances of the ciliate dominated protozoan assemblage in the study area were low compared to highly productive Adriatic bays (Revelante and Gilmartin 1983; Bojanić 2001; Bojanić et al. 2005), showing more similarity to those recorded in the mesotrophic channel areas (Bojanić 2002). Non-loricate ciliates (NLC) seemed to be regulated by salinity, rather than temperature. A similar relationship was recorded in the Kaštela Bay (Bojanic 2001). However, there are indications that the inverse relationship between NLC and salinity might be the indirect consequence of the NLC vertical distribution, since they often prefer near surface layers where food is plentiful (Bojanić et al. 2006). There was no evident influence of either temperature or salinity on total tintinnids, indicating that it might be inferred only at the species level. According to Kršinić (1980) salinity exerts a determining influence on the geographical distribution of tintinnid species along the eastern Adriatic coast, while temperature greatly impacts their seasonal succession.

Seasonal dynamics of metazoans was mostly governed by temperature, especially in the case of copepods and their developmental stages that regulated the fluctuations of mesozooplankton and metazoan microzooplankton, respectively. A similar relationship was determined for the majority of other mesozooplankton groups. For cladocerans and appendicularians a temperature-related seasonality has been frequently documented (Fonda-Umani 1980; Lučić and Onofri 1990; Isari et al. 2006). The only monospecific outburst in the Channel waters was the appearance of the cladoceran Penilia avirostris (>4000 ind $\mathrm{m}^{-3}$ ), greatly contributing to distinct summer mesozooplankton maxima at all stations in both 1998 and 1999. Similar abrupt increases of its population have been observed in other Adriatic and Mediterranean coastal areas, 
Table 6 Spearman rank order correlations between copepod groups and microzooplankton abundances
$N L C$ non-loricate ciliates, TIN tintinnides, $N A U P$ copepod nauplii, JCOP juvenile copepods, $A C O P$ adult small copepods, CALANO calanoids, CYCLO cyclopoids, POECILO poecilostomatoids, HARPAC harpacticoids

$N=11 ; * P<0.05$

$* * P<0.005$ (significant correlations are printed in bold)

\begin{tabular}{|c|c|c|c|c|c|}
\hline \multirow[t]{2}{*}{ Copepods/station } & \multicolumn{5}{|c|}{ Microzooplankton groups } \\
\hline & NLC & TIN & NAUP & JCOP & ACOP \\
\hline \multicolumn{6}{|l|}{$\mathrm{COP}$} \\
\hline S-1 & 0.264 & 0.091 & 0.000 & 0.327 & -0.068 \\
\hline $\mathrm{S}-2$ & $0.773 *$ & 0.146 & $0.637 *$ & 0.200 & 0.114 \\
\hline S-3 & 0.651 & -0.259 & 0.592 & 0.408 & 0.588 \\
\hline S-4 & -0.067 & -0.055 & -0.139 & 0.285 & -0.079 \\
\hline \multicolumn{6}{|l|}{ CALANO } \\
\hline $\mathrm{S}-1$ & 0.273 & 0.036 & -0.273 & 0.046 & -0.319 \\
\hline S-2 & $0.736 *$ & -0.055 & $0.654 *$ & 0.419 & 0.434 \\
\hline S-3 & 0.446 & -0.509 & 0.173 & 0.223 & 0.183 \\
\hline S-4 & 0.486 & -0.139 & 0.066 & 0.552 & 0.237 \\
\hline \multicolumn{6}{|l|}{ CYCLO } \\
\hline S-1 & 0.469 & -0.163 & 0.155 & 0.145 & -0.351 \\
\hline$S-2$ & $0.627 *$ & -0.027 & 0.191 & 0.005 & -0.370 \\
\hline S-3 & 0.064 & -0.209 & 0.427 & 0.181 & 0.082 \\
\hline S-4 & -0.006 & -0.188 & -0.576 & $-0.842 * *$ & $-0.869 * *$ \\
\hline \multicolumn{6}{|l|}{ POECILO } \\
\hline S-1 & 0.009 & -0.045 & 0.127 & 0.536 & 0.269 \\
\hline S-2 & 0.518 & 0.200 & $0.736^{*}$ & 0.405 & 0.443 \\
\hline S-3 & $0.609 *$ & 0.018 & $0.700 *$ & 0.582 & 0.795 \\
\hline S-4 & -0.450 & $0.636^{*}$ & 0.176 & 0.381 & 0.364 \\
\hline \multicolumn{6}{|l|}{ HARPAC } \\
\hline S-1 & -0.310 & 0.063 & 0.009 & 0.090 & 0.059 \\
\hline S-2 & 0.136 & 0.355 & 0.382 & -0.196 & -0.064 \\
\hline S-3 & 0.273 & -0.246 & 0.418 & -0.023 & 0.287 \\
\hline S-4 & -0.608 & 0.297 & -0.224 & 0.297 & 0.213 \\
\hline
\end{tabular}

relating to the species' temperature-dependant reproductive cycle (Siokou-Frangou 1996; Lipej et al. 1997; Vidjak et al. 2006).

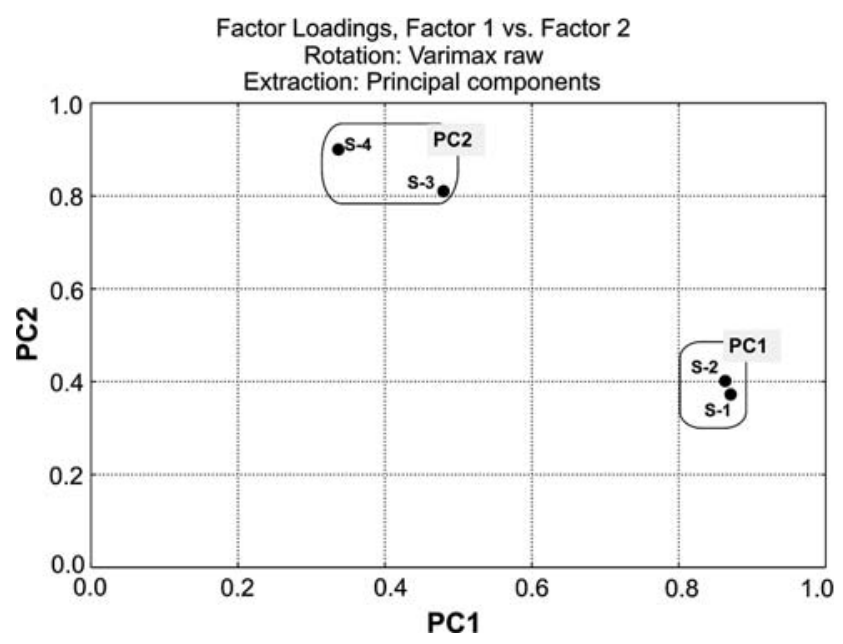

Fig. 10 Ordering of investigated stations with respect to zooplankton structure and abundance obtained by the principal component analysis (PCA)
Species succession in the copepod community was also regulated by temperature, and its fluctuations resulted in the appearance of either cryophilic (Ctenocalanus vanus, M. subtilis) or thermophilic (T. stylifera) species. However, it did not limit the presence of the most abundant small taxa such as the $O$. media complex, O. nana and E. acutifrons or Paracalanus parvus which was almost perennial at the inner stations.

Our results of the copepod seasonality are in general accordance with some earlier studies: Acartia clausi is a part of the typical summer association in the Gulf of Trieste (Cataletto et al. 1995; Mozetič et al. 2002), Kaštela Bay (Regner 1992), Gulf of Naples (Mazzocchi and Ribera d'Alcalá 1995) and Balearic Sea (Fernández de Puelles et al. 2003); Oncaea spp. belong to the autumn-winter assemblage in the Gulf of Trieste (Cataletto et al. 1995); T. stylifera characterizes the summer-autumn (Siokou-Frangou 1996), and Ctenocalanus vanus belongs to the winter community in the eastern Mediterranean (Siokou-Frangou et al. 1998).

The influence of salinity on copepod population was less clear. At the inner stations, Spearman correlations suggested a strong favourable influence of reduced salinity on 
copepod abundances, but this should be interpreted with caution. Throughout the investigated area lowest salinity values were recorded in the upper $5 \mathrm{~m}$, while deeper layers showed less oscillations and higher values. Although our sampling technique did not provide data on mesozooplankton vertical distribution, earlier investigation inside the Mali Ston Bay demonstrated significant aggregation of calanoid copepodids, $T$. longicornis, $O$. nana, O. media and E. acutifrons in deeper layers (Lučić and Kršinić 1998), where they remained unaffected by the reduced surface salinity. Moreover, among estuarine neritic copepods which might benefit from their adaptation to a wider salinity range only Acartia clausi exhibited a significant negative relationship with salinity, while the appearance and abundance of $T$. longicornis were regulated by temperature.

Apart from the physical variables of the environment, the zooplankton community is strongly influenced by food supply. Although phytoplankton is considered as the most important food item for a number of zooplankters (Kleppel 1993), chlorophyll $a$ concentrations were poorly correlated with zooplankton groups in our study. Nevertheless, distinctly reversed patterns in seasonal fluctuations of calanoid abundances and chlorophyll $a$ concentrations suggested that the grazing pressure by calanoids affects the phytoplankton biomass and that periods of low calanoid abundance can relieve that pressure thus contributing to higher phytoplankton biomass. Lawrence et al. (2004) suggested that the availability of nitrogen may indirectly control calanoid population via phytoplankton standing crop, but that an uncoupling of the calanoid abundance from nitrogen loading may occur if calanoids consume a food source that does not vary according to the nitrogen load. The same is presumably true for other omnivorous copepods. The winter mesozooplankton maxima in February 1999 at the inner stations were mainly due to copepods and bivalve larvae. The low phytoplankton biomass could hardly have supported the high calanoid and poecilostomatoid abundances ( $>4000$ ind. $\mathrm{m}^{-3}$ each) and the intensive filter-feeding from bivalve larvae. Their food requirements at that time could be met by relatively high abundances of ciliates, since there was a significant correlation between various copepod orders and ciliated protozoans. Moreover, our data showed that both NLC and small poecilostomatoids in that period preferred bottom waters, where they could interact as predator and prey. Kršinić (1987) revealed a positive correlation between tintinnids and copepod nauplii in the Mali Ston Bay winter community. The role of ciliates in the diet of bivalve molluscs in this area has also been recognized (Kršinić and Mušin 1981; Njire et al. 2004).

Although the freshwater inflow and nutrient input into the Channel waters may influence the timing and magni- tude of annual phytoplankton maxima, they did not similarly affect zooplankton community structure and abundance. High densities and dominance of omnivorous copepods regardless of the season indicated the existence of the complex food web in which herbivory is just one of the possible paths. Although the zooplankton assemblage was dominated by the neritic species, strong circulation and the compensatory inflow of the highly saline offshore waters in the bottom layer during the autumn-winter period promotes the presence of the open water zooplankton, such as small oncaeids and ostracods which are important elements of the south Adriatic winter zooplankton community (Rudenjak-Lukenda 1990; Kršinić 1998; Brautović et al. 2006). Highest values of the Shannon diversity index for the copepod community were also recorded in the colder part of the investigated period.

The differences in total micro and mesozooplankton abundances among stations were not significant, but a slight increasing trend towards the inner stations was noticed for both zooplankton size categories. The result of the PCA analysis also suggested a differentiation in the area with respect to zooplankton assemblage, thus warranting the grouping to inner and outer stations used in our paper. Due to the elongated and narrow form of the Channel, the influence of the surrounding coasts inevitably increases towards its end, culminating inside the Mali Ston Bay where high concentrations of organic and inorganic suspended particles provide favourable conditions for commercial bivalve farming (Viličić et al. 1994).

Acknowledgments This study was supported by the Ministry of Science, Education and Sports of the Republic of Croatia, as a part of the research program "Role of plankton communities in the energy and matter flow in the Adriatic Sea" (001-0013077-0845). We are indebted to Prof. Dr. Frano Kršinić (Institute of Oceanography and Fisheries Split) for help and support during the study. Thanks are also due to crew and technicians on the R/V "Bios" for their assistance during the cruises. The comments of the anonymous referees are greatly appreciated.

\section{References}

Bahun S (1981) Review of hydrogeological relations of the Maloston Bay. In: Roglić J, Meštrov M (eds) Proceedings of the symposium on Mali Ston Bay. Dubrovnik, 12-24th November 1981. Yugoslav Academy of Sciences and Arts, Zagreb, pp 22 26

Bojanić N (2001) Seasonal distribution of the ciliated protozoa in the Kaštela Bay. J Mar Biol Ass UK 81:383-390

Bojanić N (2002) Ecology of protozoa and micrometazoa in the Kaštela Bay. PhD thesis, Univ. Zagreb, Croatia

Bojanić N, Šolić M, Krstulović N, Šestanović S, Marasović I, Ninčević Ž (2005) Temporal variability in abundance and biomass of ciliates and copepods in the eutrophicated part of the Kaštela Bay (Middle Adriatic Sea). Helgol Mar Res 59:107-120 Bojanić N, Šolić M, Krstulović N, Šestanović S, Ninčević Gladan Ž, Marasović I, Brautović I (2006) The role of ciliates within 
microbial food web in the eutrophicated part of Kaštela Bay (Middle Adriatic Sea). Sci Mar 70:431-442

Böttger-Schnack R, Huys R (2001) Taxonomy of Oncaeidae (Copepoda, Poecilostomatoida) from the Red Sea. III. Morphology and phylogenetic position of Oncaea subtilis Giesbrecht, 1892. Hydrobiologia 453/454:467-481

Böttger-Schnack R, Hagen W, Schnack-Schiel SB (2001) The microcopepod fauna in the Gulf of Aqaba, northern Red Sea: species diversity and distribution of Oncaeidae (Poecilostomatoida). J Plankton Res 23:1029-1035

Böttger-Schnack R, Lentz J, Weikert H (2004) Are taxonomic details of relevance to ecologists? An example from oncaeid microcopepods of the Red Sea. Mar Biol 144:1127-1140

Brautović I, Bojanić N, Batistić M, Carić M (2006) Annual variability of planktonic ostracods (Crustacea) in the South Adriatic Sea. Mar Ecol 27:124-132

Caddy JF, Bakun A (1995) Marine catchment basins and anthropogenic effects on coastal fishery ecosystems. In: Effects of riverine inputs on coastal ecosystems and fisheries resources. FAO Fisheries Department Technical Papers 349. FAO, Rome

Cataletto B, Feoli E, Fonda-Umani S, Cheng-Yong S (1995) Eleven years of time-series on net zooplankton community in the Gulf of Trieste. ICES J Mar Sci 52:669-678

Clarke KR, Gorley RN (2001) PRIMER v5: user manual/tutorial. PRIMER-E: Plymouth

Fernández de Puelles M, Gras D, Hernandez-Leon S (2003) Annual cycle of zooplankton biomass, abundance and species composition in the neritic area of the Balearic Sea, western Mediterranean. PSZN Mar Ecol 24:123-139

Fonda-Umani S (1980) Adriatic cladocerans: a critical review. Nova Thalassia 4:107-133

Fonda-Umani S, Beran A (2003) Seasonal variations in the dynamics of microbial plankton communities: first estimates from experiments in the Gulf of Trieste, Northern Adriatic Sea. Mar Ecol Progr Ser 247:1-16

Gismervik I, Andersen T (1997) Prey switching by Acartia clausi: experimental evidence and implications of intraguild predation assessed by a model. Mar Ecol Progr Ser 157:247-259

Grasshof K (1976) Methods of seawater analysis. Verlag Chemie, Weinhein, pp 307

Isari S, Ramfos A, Somarakis S, Koutsikopoulos C, Kallianiotis A, Frangopoulu N (2006) Mesozooplankton distribution in relation to hydrology of the Northeastern Aegean Sea, eastern Mediterranean. J Plankton Res 28:241-255

Kleppel GS (1993) On the diets of calanoid copepods. Mar Ecol Progr Ser 99: $183-195$

Kršinić F (1980) Qualitative and quantitative investigations of the tintinnides along the eastern coast of the Adriatic. Acta Adriat 21:19-104 (in Croatian)

Kršinić F (1987) On the ecology of tintinnines in the Bay of Mali Ston (eastern Adriatic). Estuar Coast Shelf Sci 24:401-418

Kršinić F (1998) Vertical distribution of protozoan and microcopepod communities in the South Adriatic Pit. J Plankton Res 20:10331060

Kršinić F, Mušin D (1981) Microzooplankton of Mali Ston Bay and Malo more. In: Roglić J, Meštrov M (eds) Proceedings of the symposium on Mali Ston Bay. Dubrovnik, Croatia, 12-24th November 1981. Yugoslav Academy of Sciences and Arts, Zagreb, pp 108-119

Lawrence D, Valiela I, Tomasky G (2004) Estuarine copepod abundance in relation to season, salinity and land-derived nitrogen loading, Waquoit Bay, MA. Estuar Coast Shelf Sci 61:547-557

Lipej L, Mozetič P, Turk V, Malej A (1997) The trophic role of the marine cladoceran Penilia avirostris in the Gulf of Trieste. Hydrobiologia 360:197-203
Lučić D, Kršinić F (1998) Annual variability of mesozooplankton assemblages in Mali Ston Bay (Southern Adriatic). Period Biol 100:43-52

Lučić D, Onofri V (1990) Seasonal variation of neritic mesozooplankton in Mali Ston Bay (Southern Adriatic). Acta Adriat 31:117-137

Matić F (2005) Air-sea interaction in Split, Brač and Neretva Channel. MSc thesis, Univ. Zagreb, Croatia

Mazzocchi MG, Ribera d'Alcalá M (1995) Recurrent patterns in zooplankton structure and succession in a variable coastal environment. ICES J Mar Sci 52:679-691

Mozetič P, Fonda-Umani S, Kamburska L (2002) Plankton variability in the Gulf of Trieste (Northern Adriatic). Arch Oceanogr Limnol 23:7-19

Nakamura Y, Turner JT (1997) Predation and respiration by the small cyclopoid copepod Oithona similis: how important is feeding on ciliates and heterotrophic flagellates? J Plankton Res 19:12751288

Njire J, Bolotin J, Lučić D (2004) Importance of ciliated protozoa to the culture of the mussel Mytilus galloprovincialis L. in the Bay of Mali Ston, Croatia. Rapp Comm Int Mer Médit 37:410

Raicich F (1994) Note on flow rates of the Adriatic rivers. Istituto Talasografico Sperimentale Trieste, Technical Report, RF02/94

Regner D (1992) Eutrophication effects on the copepods in the Adriatic Sea. Fresenius Environ Bull 1:161-165

Revelante N, Gilmartin N (1983) Microzooplankton distribution in the Northern Adriatic Sea with emphasis on the relative abundance of ciliated protozoans. Oceanol Acta 6:407-415

Rudenjak-Lukenda M (1990) Annual vertical distribution of microzooplankton in the Bay of Mali Ston, Southern Adriatic (19831984). Acta Adriat 31:99-116

Siokou-Frangou I (1996) Zooplankton annual cycle in a Mediterranean coastal area. J Plankton Res 18:203-223

Siokou-Frangou I, Papathanassiou E, Lepretre A, Frontier S (1998) Zooplankton assemblages and influence of environmental parameters on them in a Mediterranean coastal area. J Plankton Res 29:847-870

Strickland JDH, Parsons TR (1972) A practical handbook of seawater analysis. Bull Fish Res Bd Can 167:1-310

Utermöhl H (1958) Zur Vervollkommung der quantitativen Phytoplankton-Methodik. Mitt Int Ver Theor Angew Limnol 9:1-38

Tičina V, Katavić I, Dadić V, Marasović I, Kršinić F, Grbec B, Kušpilić G, Cetinić P, Ninčević Gladan Ž, Matić Skoko S, Franičević M, Soldo A, Vidjak O, Emrić Tičina V, Bojanić D, Marinov S, Matić F (2006) Acoustic estimates of small pelagic fish stocks in the eastern part of Adriatic Sea: September 2003. Biol Mar Medit 13(3):124-136

Vidjak O, Bojanić N, Kušpilić G, Marasović I, Ninčević Gladan Ž, Brautović I (2006) Annual variability and trophic relations of the mesozooplankton community in the eutrophicated coastal area (Vranjic Basin, eastern Adriatic Sea). J Mar Biol Ass UK 86:19_ 26

Viličić D (1981) Phytoplankton of Mali Ston Bay and Malo more. In: Roglić J, Meštrov M (eds) Proceedings of the symposium on Mali Ston Bay. Dubrovnik, Croatia, 12-24th November 1981. Yugoslav Academy of Sciences and Arts, Zagreb, pp $77-88$

Viličić D (1989) Phytoplankton population density and volume as indicators of eutrophication in the eastern part of the Adriatic Sea. Hydrobiologia 174:117-132

Viličić D, Stojanoski L (1987) Phytoplankton response to concentration of nutrients in the central and southern Adriatic Sea. Acta Adriat 28:73-84

Viličić D, Mušin D, Jasprica N (1994) Interrelations between hydrographic conditions, nanoplankton and bivalve larvae in the Mali Ston Bay (Southern Adriatic). Acta Adriat 34:55-64 
Viličić D, Jasprica N, Carić M, Burić Z (1998) Taxonomic composition and seasonal distribution of microphytoplankton in Mali Ston Bay (eastern Adriatic). Acta Bot Croat 57:29-48

Vučak Z, Gačić M, Dadić V (1981) Characteristics of the current field in Mali Ston Bay. In: Roglić J, Meštrov M (eds) Proceedings of the symposium on Mali Ston Bay. Dubrovnik, Croatia, 12-24th November 1981. Yugoslav Academy of Sciences and Arts, Zagreb, pp 41-51
Vukadin I (1981) Hydrographic properties of Mali Ston Bay and the adjacent sea. In: Roglić J, Meštrov M (eds) Proceedings of the symposium on Mali Ston Bay. Dubrovnik, Croatia, 12-24th November 1981. Yugoslav Academy of Sciences and Arts, Zagreb, pp 52-65

Zore-Armanda M, Grbec B, Morović M (1999) Oceanographic properties of the Adriatic Sea-a point of view. Acta Adriat 40(Suppl):39-54 